\title{
OM UTSTÄLLNINGSORD
}

Ett nytt ordpar håller på att vinna insteg på utställningsområdet. Det engelska curator och det därur avledda verbet curate uppträder numera som «curator» och «curera» i samband med utställningar av bildkonst (stavningen, får man tro, för att undvika de i sammanhanget opassande associationerna till kurator och kurera). Ordbruket har antagligen samband med problem som uppstått, när konceptkonst och installationer blivit allt vanligare fenomen. De utställningsformer och hängningskonventioner som varit en självklar del av konstintendenters kunnande räcker inte till för de nya uttrycksformerna - en ny beteckning för verkpresentationens regikonst har ansetts behövlig.

Men en blick på kultur- och naturhistoriska museer, som burit på ett estetiskt arv från konstmuseernas utställande, dock sedan länge brutit med detta, kunde kanske ha varit till hjälp. Där har de utställningsansvariga utvecklat ett brett spektrum av nya utställningsformer. Ibland har en producent haft hela ansvaret; allt vanligare har blivit att producenten tagit hjälp av arkitekt, formgivare, scenograf och andra specialister i ett samarbete där det kan vara svårt att värdera betydelsen av de enskilda insatserna. Producenten har emellertid haft det slutliga ansvaret för den visuella helhetsgestaltningen.

I föreliggande (utställnings)nummer framgår att de nya orden är på väg över gränsen till kulturhistoriska utställningar. Så hänvisar Mordhorsts och Jensens uppsats genomgående till Berlin-utställningens «kuratorer». Den faktiska komplexiteten i samspelet mellan olika kompetenser i ett utställningslag belyses av Margareta Bergvalls skildring av en ny utställning i Länsmuseet Västernorrland, Härnösand. Hon pekar på tre tolkningsvägar som är grundläggande i en historisk utställning den teoretisk/vetenskapliga, den praxisorienterade och den konstnärliga/inlevelsegrundade. Alla tre måste beredas utrymme i utställningsgestaltningen. Angela Fussell skriver om en etnologisk utställning som genom integrationen med tillämpad datorteknik ger en ny ansvarsfördelning mellan producent och tekniker. Och Katja Lindqvist om konstnären som iscensättare och den gränsöverskridande betydelse som en konstnärs insats kan få för en multidisciplinär, situationsspecifik och dialog- 
NORDISK MUSEOLOGI $1997 \cdot 1$

2 inriktad museiutställning. Gösta Salén slutligen, visar hur en arkitekt kan forma rummet för att styra utställningsreceptionen.

«Betraktade som utsagor är det svårt att skilja på museal förmedling och konstnärlig», skriver Katja Lindqvist. Den avgörande skillnaden mellan konstutställningen och den historiska utställningen är dock det verifierbara korrelat i ett källmaterial som den senare har. Rolf Gillberg berör detta i sin uppsats: "Ingen udstilling er objektiv. Jeg kan ikke lave om genstandene, men jeg kan trække visse sider mere frem end andre. Jeg kan udelade og tilføje alt efter mit forgodtbefindende.» Och med texternas hjälp foga in dem i bestämda förståelseramar. Men vem bestämmer, eller med andra ord: «Hvem ejer fortiden? Eller er det hvem ejer for tiden?»

I konstutställningen uppstår uppenbarligen också en rollosäkerhet - är utställningsarrangören eller konstnären utställare? Problemet berördes av Vibeke Petersen i förra numret, när hon skrev om utställningsarrangören som utställningens iscensättare.

Problemen har fătt sin polemiska belysning i en tidningsdebatt omkring utställningen Den starke kvinden, visad ICOM-sommaren 1995 i Stavanger, nu på besök i Historiska museet i Stockholm. Utställningens syn på kvinnans förändrade ställning i samhället som en följd av kristendomens införande, har utsatts för frän kritik. "Det förflutna ställer ett antal spår till förfogande, och vi kan välja bland fragmenten tills vi får en bild som passar oss. De döda kan inte springa efter oss och säga att vi missförstått dem», skriver en kritiker och menar att Historiska museet som utställningsarrangör har försummat sitt ansvar som garant för utställningens trovärdighet: "Hundratals skolklasser skall nu fösas mellan montrarna och lära sig av beskäftiga textskyltar att kristendomen har inneburit en katastrof för kvinnan.» De ansvariga producenterna, Inga Lundström och Oddveig Foldöy, försvarar sig med att - inom en institution som i övrigt erbjuder en rik saklig redovisning - just «de tillfälliga utställningarna ger möjlighet till experimenterande tolkningar och tillspetsningar». De kan därigenom stimulera publikens intresse och engagemang.

Men det är tvivelaktigt om införandet av de nya orden curator och curera gör situationen tydligare och inte bara bidrar till att skymma den grundläggande likheten mellan konstmuseers och historiska museers utställningar. 